\title{
Article \\ A New Perspective on the Role of Glutamine Synthetase in Nitrogen Remobilization in Wheat (Triticum aestivum L.)
}

\author{
Yihao Wei ${ }^{1,+}$, Lulu Wang ${ }^{1,+}{ }^{+}$Butan Qin ${ }^{1}$, Huiqiang Li ${ }^{2}$, Xiaoran Wang ${ }^{2}$, Zhiyong Zhang ${ }^{1}$, Xiaobo Zhu ${ }^{2}$, \\ Xinming Ma ${ }^{1, \ddagger}$ and Xiaochun Wang ${ }^{1,2, *}$ \\ 1 Collaborative Innovation Center of Henan Grain Crops, College of Agronomy, Henan Agricultural University, \\ Zhengzhou 450000, China; yihaowei@stu.henau.edu.cn (Y.W.); wl19501@stu.henau.edu.cn (L.W.); \\ qinbutan@stu.henau.edu.cn (B.Q.); zhiyongzhang@henau.edu.cn (Z.Z.); maxinming@henau.edu.cn (X.M.) \\ 2 Department of Biochemistry and Molecular Biology, College of Life Science, Henan Agricultural University, \\ Zhengzhou 450000, China; huiqiangli@henau.edu.cn (H.L.); xiaoranwang@henau.edu.cn (X.W.); \\ xiaobo2021@stu.henau.edu.cn (X.Z.) \\ * Correspondence: xiaochunwang@henau.edu.cn \\ + These authors have contributed equally to this work. \\ $\ddagger$ Senior author.
}

check for updates

Citation: Wei, Y.; Wang, L.; Qin, B.; Li, H.; Wang, X.; Zhang, Z.; Zhu, X.; Ma, X.; Wang, X. A New Perspective on the Role of Glutamine Synthetase in Nitrogen Remobilization in Wheat (Triticum aestivum L.). Int. J. Mol. Sci. 2021, 22, 11083. https://doi.org/ $10.3390 /$ ijms222011083

Academic Editor: Abir U. Igamberdiev

Received: 18 September 2021

Accepted: 11 October 2021

Published: 14 October 2021

Publisher's Note: MDPI stays neutral with regard to jurisdictional claims in published maps and institutional affiliations.

Copyright: (c) 2021 by the authors. Licensee MDPI, Basel, Switzerland. This article is an open access article distributed under the terms and conditions of the Creative Commons Attribution (CC BY) license (https:// creativecommons.org/licenses/by/ $4.0 /)$.

\begin{abstract}
Glutamine synthetase (GS), a key enzyme in plant nitrogen metabolism, is closely related to nitrogen remobilization. However, how GS isoforms participate in nitrogen remobilization remains unclear. Here, the spatiotemporal expression of the TaGS gene family after anthesis was investigated, and the results showed that TaGS1;1 was mainly encoded by TaGS1;1-6A, while the other isozymes were mainly encoded by TaGS localized on the A and D subgenomes. TaGS1;2-4A/4D had the highest expression level, especially in rachis and peduncle. Furthermore, immunofluorescence showed TaGS1;2 was located in the phloem of rachis and peduncle. GUS ( $\beta$-glucuronidase) staining confirmed that ProTaGS1;2-4A/4D::GUS activity was mainly present in the vascular system of leaves, roots, and petal of Arabidopsis. Ureides, an important transport form of nitrogen, were mainly synthesized in flag leaves and transported to grains through the phloem of peduncle and rachis during grain filling. TaAAH, which encodes the enzyme that degrades ureides to release $\mathrm{NH}_{4}{ }^{+}$, had a higher expression in rachis and peduncle and was synchronized with the increase in $\mathrm{NH}_{4}{ }^{+}$ concentration in phloem, indicating that $\mathrm{NH}_{4}{ }^{+}$in phloem is from ureide degradation. Taking the above into account, TaGS1;2, which is highly expressed in the phloem of peduncle and rachis, may participate in $\mathrm{N}$ remobilization by assimilating $\mathrm{NH}_{4}{ }^{+}$released from ureide degradation.
\end{abstract}

Keywords: nitrogen use efficiency; grain filling; phloem; nucleic acid; ureides; degradation; ammonium assimilation

\section{Introduction}

Wheat (Triticum aestivum L.) is one of the most important cereal crops cultivated worldwide and is mainly used for human consumption [1]. Nitrogen $(\mathrm{N})$ is a key limiting factor for the yield and quality of wheat [2,3]. However, excessive application of nitrogen fertilizer not only causes economic losses but also leads to environmental pollution, which is a stumbling block to the sustainable development of agriculture. Improving nitrogen use efficiency is an effective strategy to remove this obstacle [3-6].

Nitrogen utilization of wheat includes nitrogen absorption, assimilation, translocation, and remobilization. Efficient $\mathrm{N}$ remobilization during grain filling is crucial to improve nitrogen use efficiency $[7,8]$. In wheat, $60 \%$ to $95 \%$ of grain $\mathrm{N}$ at harvest comes from the remobilization of $\mathrm{N}$ stored before anthesis. The glutamine synthetase (GS; EC 6.3.1.2) activity is highly correlated with the amount of $\mathrm{N}$ remobilized and the grain yield [2,8-12].

GS catalyzes the ATP-dependent fixation of ammonium $\left(\mathrm{NH}_{4}{ }^{+}\right)$to the glutamate $(\mathrm{Glu})$ to form glutamine (Gln) [13]. According to subcellular location, plant GS is classified 
into two groups: the cytosolic glutamine synthetase (GS1) and the chloroplast glutamine synthetase (GS2) [14]. In diploid plants, such as Arabidopsis, rice, and maize, GS1 is encoded by $3-5$ nuclear genes, while GS2 is encoded by a single nuclear gene [15]. In hexaploid wheat $(2 \mathrm{n}=42$, AABBDD genomes), TaGS1 is encoded by nine nuclear genes, while TaGS2 is encoded by three nuclear genes [16]. According to phylogenetic tree analysis of GS isoforms of cereals, the TaGS gene family is classified into four subfamilies: TaGS1;1$6 A / 6 B / 6 D, T a G S 1 ; 2-4 A / 4 B / 4 D, T a G S 1 ; 3-4 A / 4 B / 4 D$, and TaGS2-2A/2B/2D [15]. Recent studies have mainly focused on the functional differences between TaGS1;1, TaGS1;2, TaGS1;3, and TaGS2 [17-19].

TaGS2, located in chloroplasts, is the predominant isozyme in green tissue, and its dominating role is in the reassimilation of $\mathrm{NH}_{4}{ }^{+}$released by photorespiration and assimilation of $\mathrm{NH}_{4}{ }^{+}$derived from $\mathrm{NO}_{3}{ }^{-}$reduction $[20,21]$. TaGS1;3, located in the pericycle and endodermis of roots, is mainly involved in the assimilation of $\mathrm{NH}_{4}{ }^{+}$absorbed by roots. TaGS1;3 is also located in the aleurone layer and endosperm transfer cells of grains, which may play a key role in transporting Gln into the endosperm for gluten synthesis [17]. In flag leaves, the TaGS1;1 transcript is located in the perifascicular sheath cell and TaGS1;2 transcript is present in the vascular phloem cells and the parenchyma cells close to the xylem [18]. They are involved in $\mathrm{N}$ remobilization by assimilating $\mathrm{NH}_{4}{ }^{+}$from protein turnover during leaf senescence $[15,18]$. However, TaGS1;1 and TaGS1;2 proteins are located in the mesophyll cells and xylem of leaves, respectively [19]. The differences in localization at the protein and mRNA levels highlight the importance of studying TaGS protein localization. Moreover, the transcripts of TaGS1;1 and TaGS1;2 are also located in the parenchyma cells near the vascular tissue and vascular cells of stem and rachis [18]. However, the relationship between TaGS and nitrogen remobilization in these organs is not clear.

Nitrogen remobilization mainly occurs during tissue senescence. During the grain filling of wheat, $\mathrm{N}$-containing organics in the senescence source organs (leaves) are degraded into small molecules in order to be transported into the sink organs (grains) through the vascular tissue of peduncle and rachis [7,22-27]. Sink organs generally display little need for xylem due to their low transpiration rates, so $\mathrm{N}$ partitioning from the source leaves to sinks occurs in the phloem [28]. Protein and nucleic acid in flag leaves are important sources of organic nitrogen in preanthesis wheat [27,29]. During flag leaf senescence, the amino acids generated during protein turnover are transferred to grains via phloem, mainly in the form of Gln and alanine (Ala) [7]. Among the degradation products of nucleic acids, purine has the highest nitrogen content, and its degradation product, ureides, is one of the most important forms of transport for organic nitrogen. Ureide degradation can release four molecules of $\mathrm{NH}_{4}{ }^{+}$[26], which are likely to be reassimilated by GS into Gln. During the transportation of ureides from the source organs to grains via the peduncle and rachis, if ureides is degraded and releases $\mathrm{NH}_{4}{ }^{+}$, then this part of $\mathrm{NH}_{4}{ }^{+}$assimilation may be related to TaGS in the peduncle and rachis.

Not only do the four TaGS isozymes have different functions but the three TaGS genes in the same subfamily also have different functions [30-32]. Quantitative trait locus (QTL) analyses in wheat has shown that the QTL for GS activity of flag leaves only colocalizes with TaGS2-2A and TaGS1;2-4A among the $12 \mathrm{TaGS}$ genes [32], and only TaGS2-2B, TaGS1;2$4 A$, and TaGS1;3-4A are associated with the QTL for grain protein content [30-32]. The promoter elements of three TaGS genes in the same subfamily are different [16], which may indicate that the TaGS genes in the same subfamily have different expression patterns and regulation mechanisms. Therefore, investigating the promoter activity of the $12 \mathrm{TaGS}$ genes, detecting the spatiotemporal expression of the TaGS gene family, and analyzing ureide metabolism during the grain filling of wheat will help us elucidate how TaGS isozymes participate in $\mathrm{N}$ remobilization by $\mathrm{NH}_{4}{ }^{+}$assimilation. Here, we discovered that TaGS1;2, located in the phloem of peduncle and rachis, may participate in nitrogen remobilization by assimilating $\mathrm{NH}_{4}{ }^{+}$released from ureide degradation. 


\section{Results}

\subsection{The Spatiotemporal Expression Profile of TaGS Gene Family}

In order to investigate the function of TaGS in nitrogen remobilization from source (flag leaf) to sink (grain) through peduncle and rachis, the spatiotemporal expression patterns of the TaGS gene family during grain filling were explored by qRT-PCR. The results showed that TaGS1;1-6A was the major gene encoding TaGS1;1, and TaGS1;2 was mainly encoded by TaGS1;2-4A and TaGS1;2-4D. TaGS1;2-4A/4D had the highest expression level in the TaGS gene family. The genes encoding TaGS1;3 and TaGS2 were localized on the A, B, and D subgenomes, and the genes located in the D and A subgenomes had a higher expression (Figure 1). Under different nitrogen application conditions, most TaGS genes expressed did not change significantly except that TaGS1;2$4 A / 4 D$ in rachis and $T a G S 2-2 A / 2 D$ in flag leaves had a higher expression level under N225 than N120 (Figure 1).

There were significant differences in the expression levels of TaGS genes in different organs. TaGS1;1-6A was extensively expressed in flag leaf, sheath, peduncle, rachis, and grain; TaGS1;2-4A and TaGS1;2-4D were mainly expressed in peduncle and rachis; TaGS1;3$4 A / 4 B / 4 D$ were mainly expressed in grain; and $T a G S 2-2 A / 2 B / 2 D$ were mainly expressed in flag leaf (Figure 1). With the senescing of flag leaves, the expression levels of TaGS1;1-6A in flag leaves gradually decreased, while the expression levels of TaGS1;2-4A/4D gradually increased (Figure 1), suggesting that TaGS1;2 may play a more important role in nitrogen remobilization.

\subsection{Promoter Activities of TaGS Gene Family}

To investigate the reasons for differential expression of the TaGS gene family, the expression patterns of GUS driven by the promoters of $12 \mathrm{TaGS}$ genes in transgenic Arabidopsis were analyzed. By comparing the expression level of GUS, the activity of ProTaGS1;1$6 A / 6 B / 6 D$ and ProTaGS1;2-4A/4B/4D were consistent with the expression trend of their corresponding genes in wheat. ProTaGS1;1-6A had a much higher activity than ProTaGS1;1$6 B / 6 D$. The expression level of GUS controlled by ProTaGS1;2-4A/4D was tenfold that of ProTaGS1;2-4B, the two most active promoters of the TaGS gene family (Figure 2a). However, the activity of ProTaGS1;3-4A/4B/4D and ProTaGS2-2A/2B/2D was not consistent with the expression level of their corresponding genes in wheat. The activity of ProTaGS1;3-4B was much higher than that of ProTaGS1;3-4A/4D, while ProTaGS2-2A/2B was approximately 15 times more active than ProTaGS2-2D (Figure 2a).

The blue signal was detected in the ProTaGS1;2-4A/4B/4D::GUS transgenic plants and was mainly present in the vascular tissues of the roots, hypocotyl, leaves, flowers, and the bottom of the siliques (Figure 2b). No obvious GUS activity was detected in the other transgenic plants. In addition, there were significant differences in the activities of the three promoters. GUS activity controlled by ProTaGS1;2-4A/4D was significantly higher than that controlled by ProTaGS1;2-4B (Figure 2b), consistent with the expression level of TaGS1;2-4A/4B/4D in wheat (Figure 1). 
Flag leaf
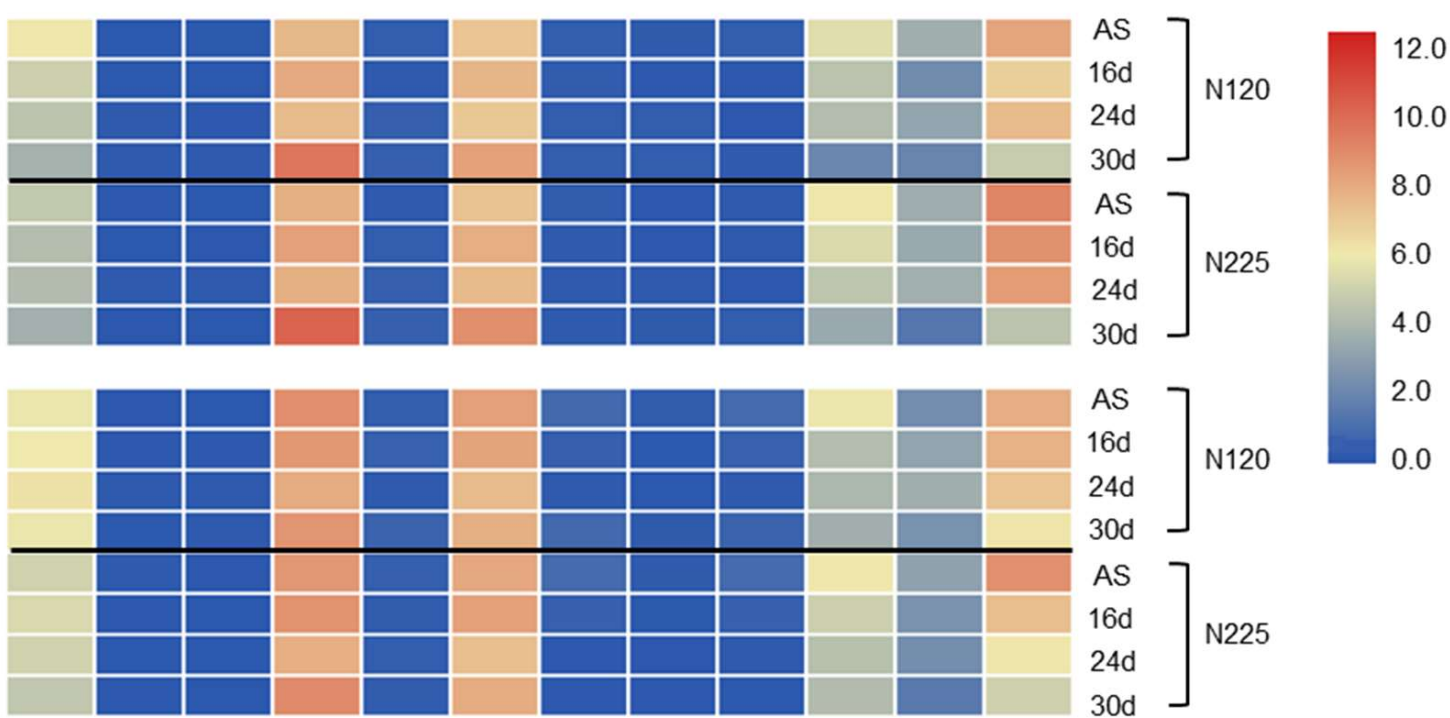

Peduncle

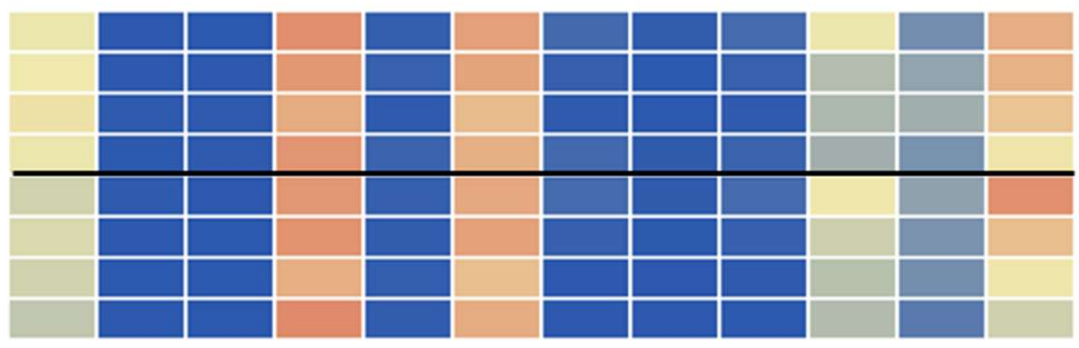

Sheath
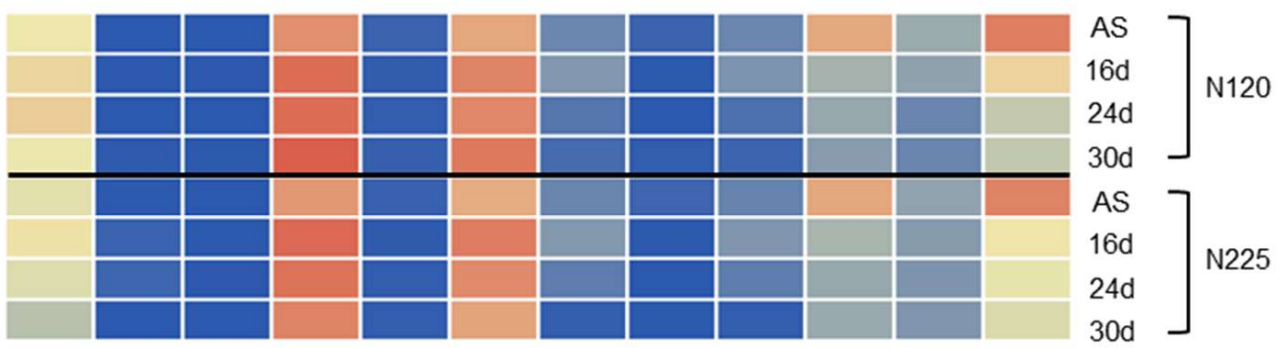

Rachis
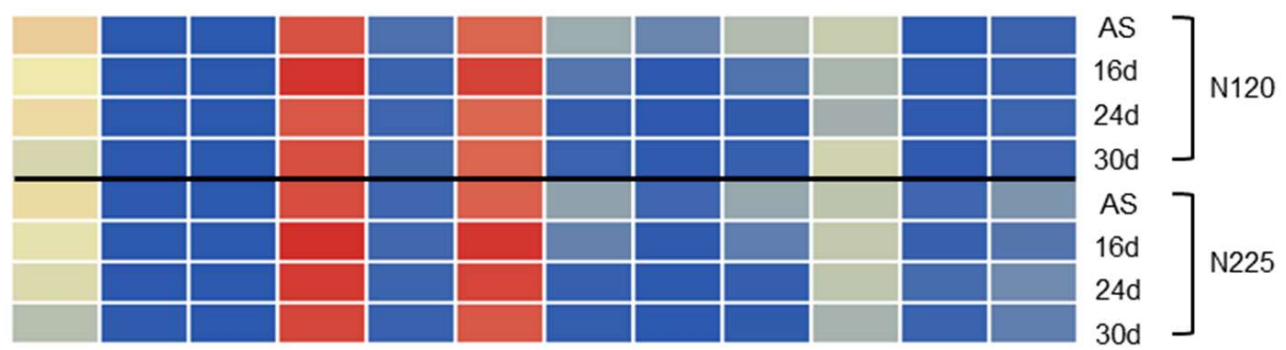

Grain
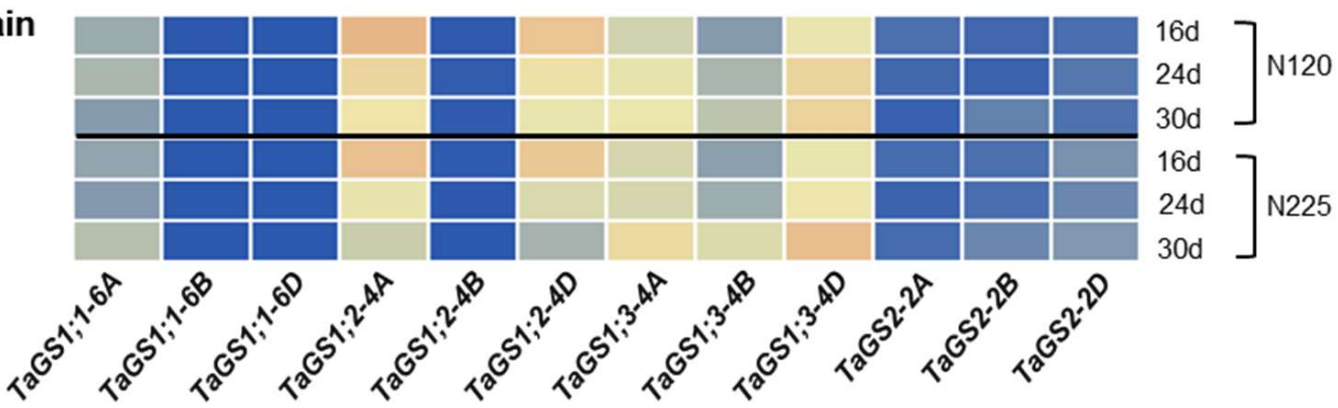

Figure 1. Heatmap of $T a G S$ gene expression profiles in different organs in relation to $\mathrm{N}$ fertilization and development by qRT-PCR. The geometric mean of $C_{t}$ values of TaATPases and TaTEF served to normalize the expression ratio for each gene. Data are means of six independent biological replicates. Gene expression data are shown as $\log _{2}$-transformed data of normalized data +1 . AS, anthesis stage; $16 \mathrm{~d}, 24 \mathrm{~d}$, and $30 \mathrm{~d}$ represent 16,24 , and 30 days after anthesis (DAA), respectively; N120, $120 \mathrm{~kg} \mathrm{~N} \mathrm{ha}^{-1}$; N225, $225 \mathrm{~kg} \mathrm{~N} \mathrm{ha}^{-1}$. 
(a)

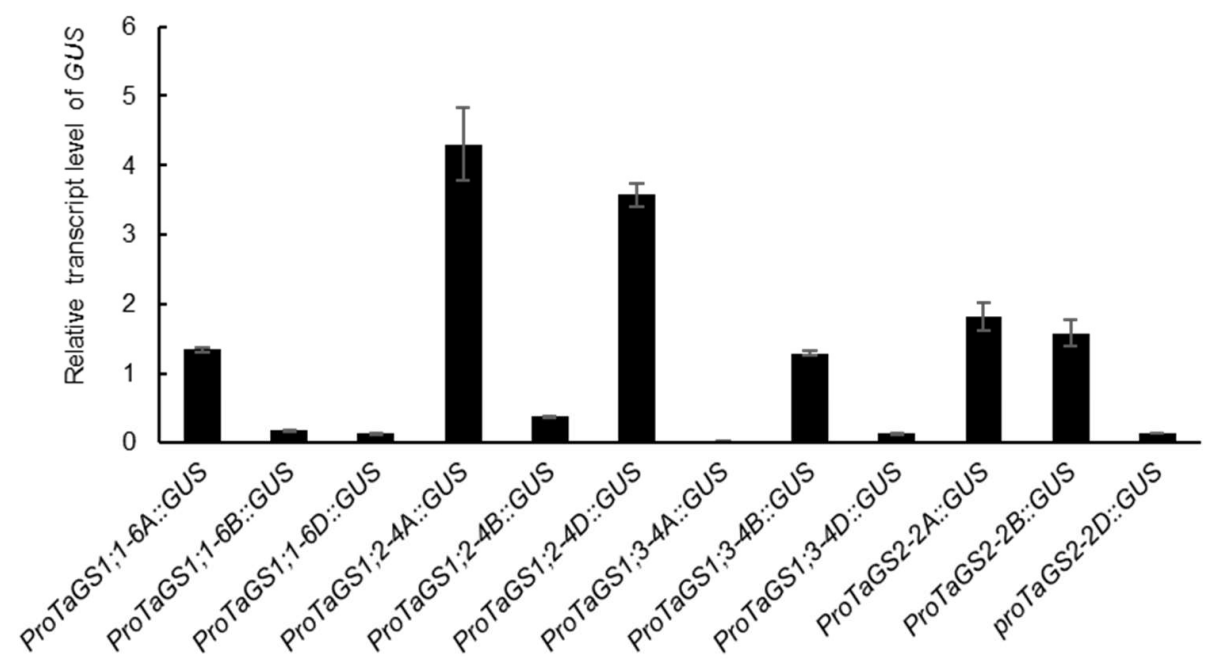

(b)
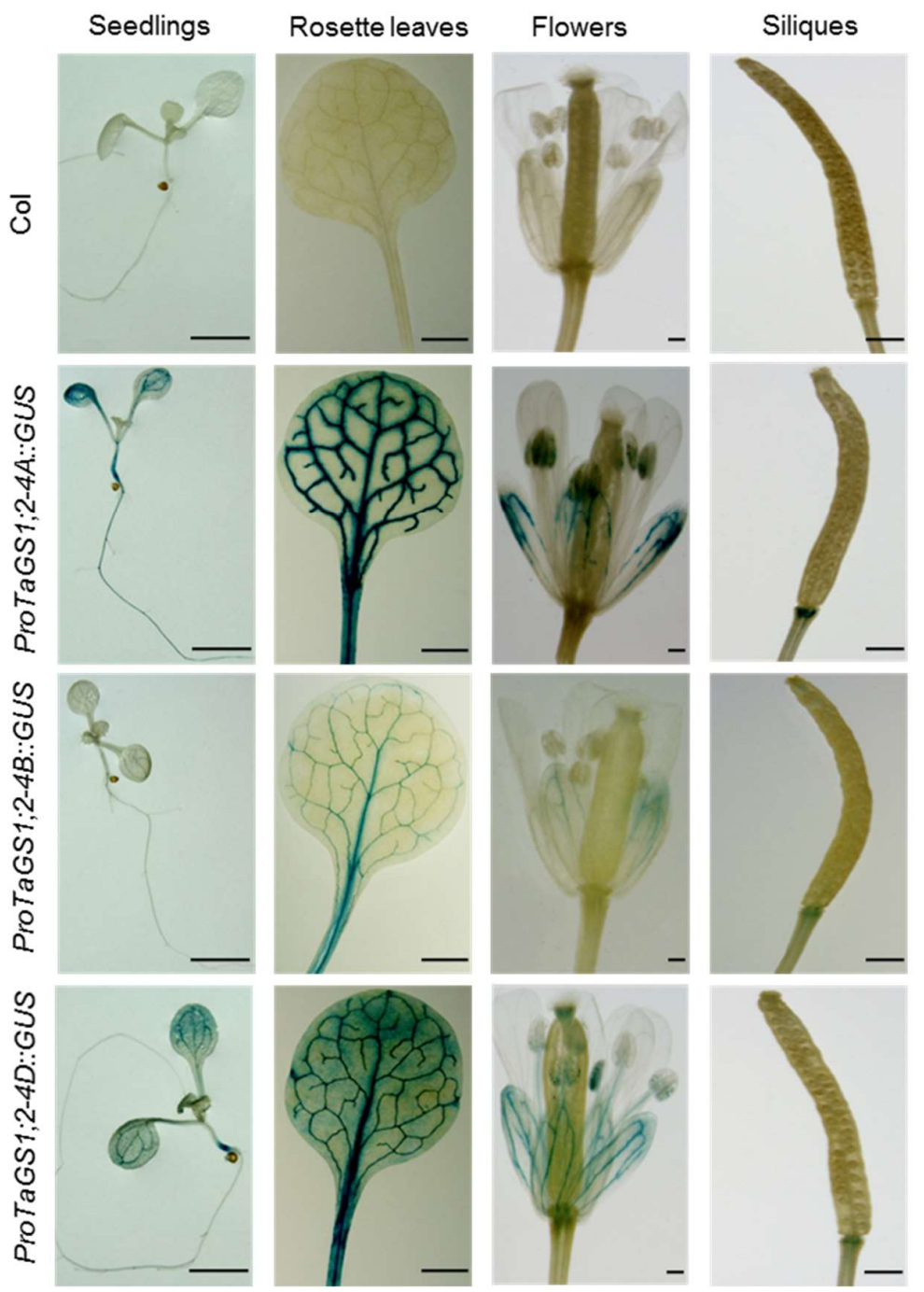

Figure 2. Patterns of GUS expression driven by the promoters of the TaGS genes in Arabidopsis. Transgenic lines were transformed with transcriptional fusions between the TaGS gene promoter and the GUS reporter gene. (a) qRT-PCR analysis of GUS expression in transgenic lines. Gene expression levels were normalized to reference gene AtUBQ11. Data are means of three independent biological replicates \pm SD. (b) GUS staining was observed in $10 \mathrm{~d}$ old seedlings, rosettes leaves of $25 \mathrm{~d}$ old plants, and flowers and siliques of $40 \mathrm{~d}$ old plants. The blue signal indicates GUS activity. Scale bars are $1 \mathrm{~mm}$. 


\subsection{TaGS1;2 Located in Phloem of Peduncle and Rachis Participates in N Remobilization}

GUS, driven by ProTaGS1;2-4A/4B/4D, is widely expressed in vascular tissues of Arabidopsis, indicating that TaGS1;2 may be related to nitrogen transport. Using specific antibodies of TaGS1;2 as a probe, the localization of TaGS1;2 in the flag leaf, peduncle, and rachis of wheat was studied by immunofluorescence. The results showed that TaGS1;2 was mainly located in the vascular tissues of wheat, including the xylem of flag leaf and the phloem of peduncle and rachis (Figure 3a). During grain filling, nutrients from the source organs are mainly transported to the grain through the phloem. Therefore, TaGS1;2 located in the phloem may play an important role in the transportation of nitrogen to the grain.

During grain filling, $\mathrm{NH}_{4}{ }^{+}$content in the phloem exudate of flag leaf was extremely low, but the content of $\mathrm{NH}_{4}{ }^{+}$in the phloem exudate of peduncle was very high. An increase in nitrogen application could significantly increase the $\mathrm{NH}_{4}{ }^{+}$content (Figure $3 \mathrm{~b}$ ). Under the condition of $\mathrm{N} 225$, the content of $\mathrm{NH}_{4}{ }^{+}$in the phloem exudate of peduncle was about 100 times that in the phloem exudate of flag leaf (Figure 3b). TaGS1;2 located in the phloem of peduncle and rachis that transport large $\mathrm{NH}_{4}{ }^{+}$and the expression of TaGS1;2 in rachis increased with the increase in $\mathrm{NH}_{4}{ }^{+}$content in phloem, and the expression level of TaGS1;2 under N225 was higher than that under N120 (Figure 3c). The high expression of TaGS1;2 in the phloem of rachis coincided with the high $\mathrm{NH}_{4}{ }^{+}$export, suggesting that TaGS1;2 assimilates $\mathrm{NH}_{4}{ }^{+}$in the phloem into Gln and is involved in the transportation of nitrogen to grain.

\subsection{The $\mathrm{NH}_{4}{ }^{+}$in Phloem of Peduncle and Rachis Is from the Degradation of Ureides}

In order to investigate the sources of $\mathrm{NH}_{4}{ }^{+}$in phloem, ureide metabolism during the grain filling of wheat was analyzed. Ureides includes allantoin and allantoate [33]. Xanthine dehydrogenase (TaXDH1) and urate oxidase (TaUOX), which are involved in wheat allantoin biosynthesis [27], were mainly expressed in flag leaves and significantly increased in the late stage of grain filling (Figure 4a). Ureides was mainly synthesized in flag leaves and then exported to the peduncle via the phloem, and the export of ureides reached the maximum at 30 DAA (Figure $4 \mathrm{~b}, \mathrm{f}$ ). These results show that the synthesis and export of ureides mainly occurred during flag leaf senescence.

During the early grain filling stage, ureides accumulated in the peduncle (Figure 4c), and the export of ureides from peduncle to grain was lower (Figure $4 \mathrm{~g}$ ). With the development of grains, the rate of ureides export from peduncle increased significantly (Figure 4g), and the grains gradually became the main storage organ for ureides (Figure 4e).

Allantoin is metabolized into allantoate by allantoinas allantoinase (TaALN), and allantoate amidohydrolase $(\mathrm{TaAAH})$ catalyzes the degradation of allantoate to produce $\mathrm{NH}_{4}{ }^{+}$[27]. During the late grain-filling stage, the expression levels of $T a A L N$ and $T a A A H$ in flag leaves were significantly lower than those in the peduncle, rachis, and grain (Figure 4a). Especially under N225 conditions, the expression level of TaAAH in grains at 30 DAA was about 10 times that in flag leaves (Figure 4a). The results indicate that the degradation of ureides mainly occurs in the peduncle and rachis that transports ureides and in the grains that stores ureides. Compared with N120, TaAAH had higher expression levels in peduncle, rachis, and grain under $\mathrm{N} 225$, and the corresponding $\mathrm{NH}_{4}{ }^{+}$content in the phloem was higher (Figures $3 \mathrm{~b}$ and $4 \mathrm{a}$ ). The phloem of rachis is an important channel for ureides to enter the grain. In rachis, the synthesis and accumulation of ureides was extremely low (Figure 4a,d), but the expression of $\mathrm{TaAAH}$ was high (Figure 4a). These results support the hypothesis that $\mathrm{NH}_{4}{ }^{+}$in the phloem is from the degradation of ureides. 
(a)
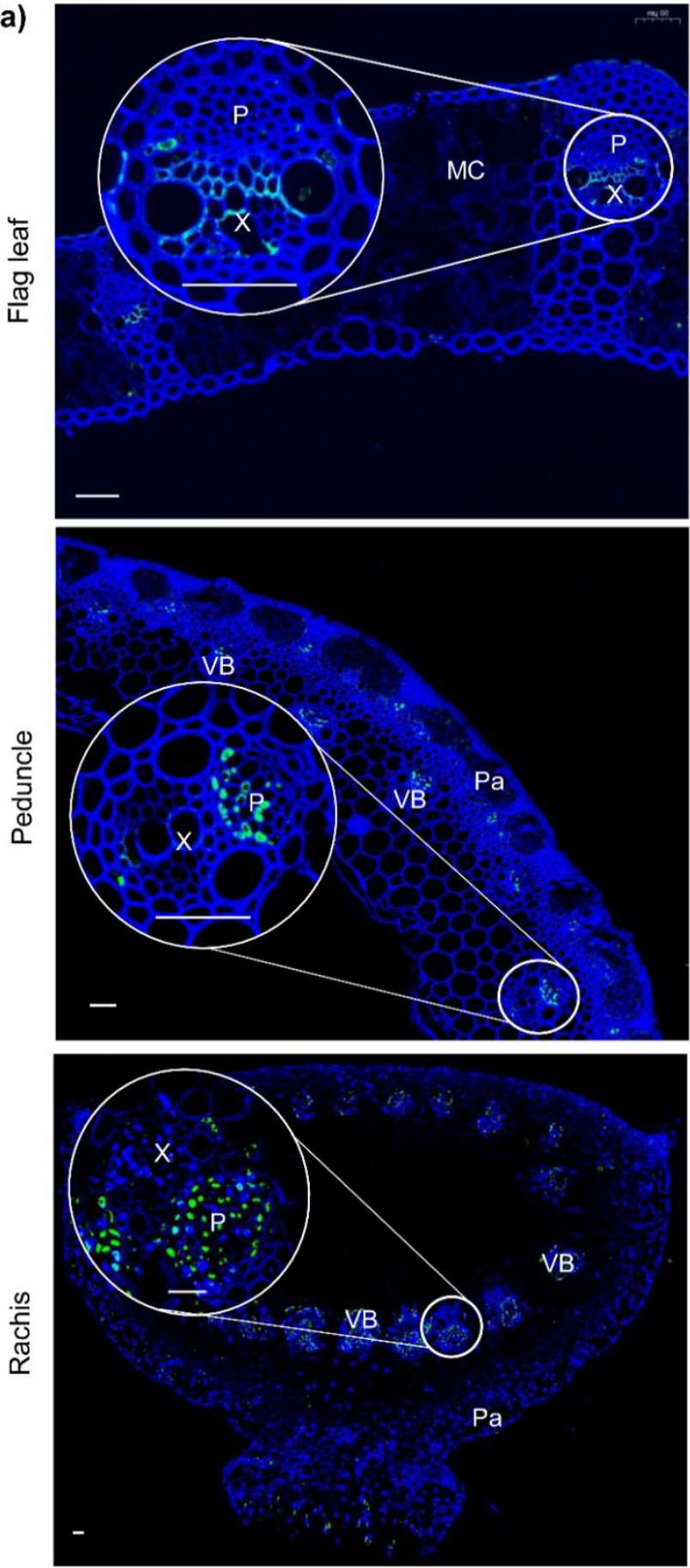

(b)

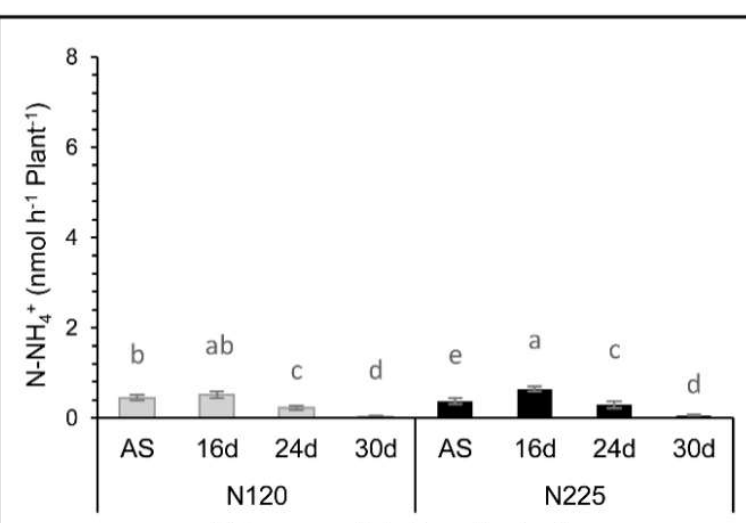

Phloem exudate from flag leaf

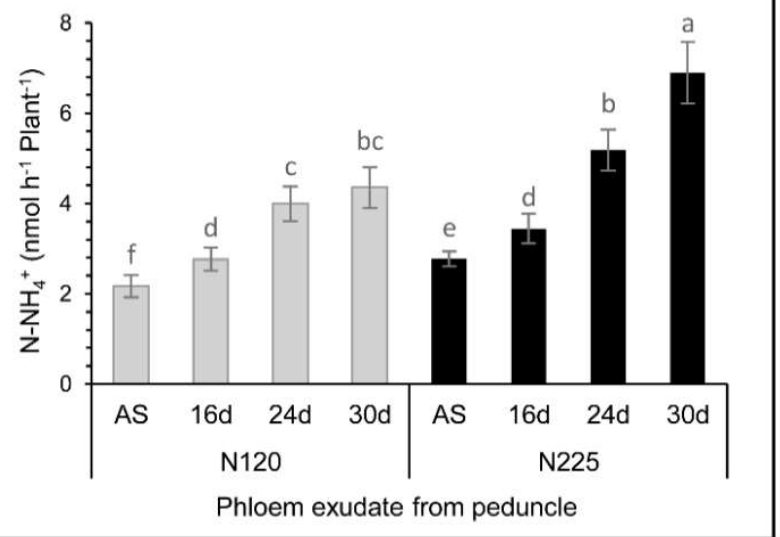

(c)

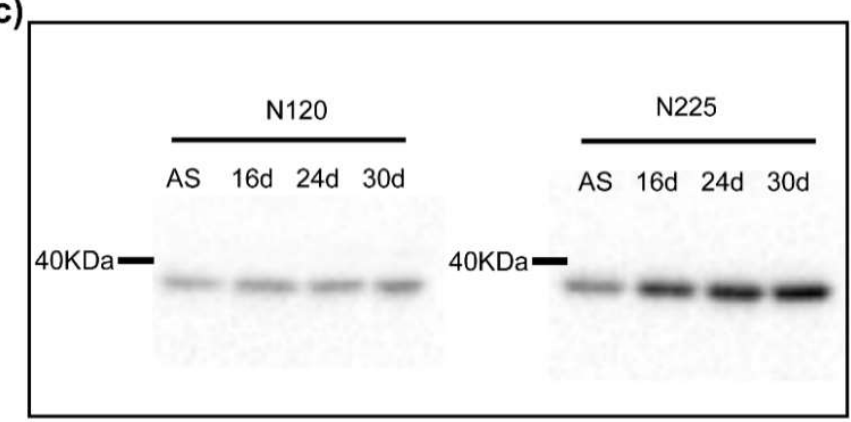

Figure 3. TaGS1;2 involved in nitrogen remobilization by $\mathrm{NH}_{4}{ }^{+}$assimilation in the phloem of wheat. (a) Histological immunolocalization of TaGS1;2 in flag leaf, peduncle, and rachis transverse section. P, phloem; X, xylem; VB, vascular bundle; $\mathrm{Pa}$, parenchyma. Bars $=50 \mu \mathrm{m}$. (b) The content of $\mathrm{NH}_{4}{ }^{+}$in the phloem exudate of flag leaf and peduncle during grain filling. Data are the means of six independent biological replicates \pm SD. The different letters above each sample indicate statistically significant differences, where $p<0.05$ according to one-way ANOVA and Duncan post-hoc test. (c) Western blot analysis of expression profile of subunits in rachis during grain filling grown under N120 and N225 conditions. A total of $5 \mu \mathrm{g}$ of soluble proteins extracted from the rachis was loaded in each lane. 
(a)

\begin{tabular}{|c|c|c|c|c|c|c|}
\hline \multirow[t]{8}{*}{ Flag leaf } & 9.59 & 5.40 & 4.53 & 3.71 & AS & \multirow{3}{*}{$\mathrm{N} 120$} \\
\hline & 13.91 & 9.59 & 2.54 & 4.94 & $16 \mathrm{~d}$ & \\
\hline & 20.38 & 14.21 & 2.55 & 4.15 & $24 \mathrm{~d}$ & \\
\hline & 72.89 & 41.50 & 3.75 & 4.82 & 30d & \multirow{5}{*}{ N225 } \\
\hline & 5.41 & 2.16 & 4.62 & 3.90 & AS 7 & \\
\hline & 9.76 & 6.24 & 2.19 & 3.44 & $16 \mathrm{~d}$ & \\
\hline & 15.44 & 10.95 & 2.47 & 2.78 & $24 \mathrm{~d}$ & \\
\hline & 54.94 & 37.45 & 2.80 & 3.68 & 30d & \\
\hline \multirow{8}{*}{ Peduncle } & 3.20 & 3.41 & 1.60 & 3.22 & AS 7 & \multirow{4}{*}{ N120 } \\
\hline & 11.13 & 8.75 & 6.07 & 5.22 & $16 \mathrm{~d}$ & \\
\hline & 12.28 & 8.12 & 7.69 & 8.58 & $24 \mathrm{~d}$ & \\
\hline & 21.84 & 15.69 & 7.71 & 13.24 & $30 \mathrm{~d}$ & \\
\hline & 2.40 & 3.03 & 1.00 & 3.16 & AS 7 & \multirow{4}{*}{ N225 } \\
\hline & 4.60 & 6.77 & 3.18 & 4.88 & $16 \mathrm{~d}$ & \\
\hline & 8.36 & 7.45 & 6.07 & 14.38 & $24 \mathrm{~d}$ & \\
\hline & 11.55 & 10.63 & 6.91 & 15.70 & $30 \mathrm{~d}$ & \\
\hline \multirow[t]{8}{*}{ Rachis } & 4.02 & 7.61 & 4.39 & 5.33 & AS 7 & \multirow{4}{*}{ N120 } \\
\hline & 5.77 & 9.51 & 7.26 & 3.99 & $16 \mathrm{~d}$ & \\
\hline & 6.92 & 7.48 & 4.44 & 5.96 & $24 \mathrm{~d}$ & \\
\hline & 8.51 & 8.33 & 2.06 & 10.37 & $30 \mathrm{~d}$ & \\
\hline & 3.07 & 4.43 & 3.63 & 4.46 & AS & \multirow{4}{*}{ N225 } \\
\hline & 4.49 & 4.13 & 5.94 & 3.86 & $16 \mathrm{~d}$ & \\
\hline & 4.95 & 5.27 & 4.24 & 8.64 & $24 \mathrm{~d}$ & \\
\hline & 6.88 & 6.73 & 5.84 & 17.39 & $30 \mathrm{~d}$ & \\
\hline \multirow[t]{7}{*}{ Grain } & 2.18 & 8.12 & 15.15 & 16.94 & $16 \mathrm{~d}$ & \multirow{3}{*}{$\mathrm{N} 120$} \\
\hline & 10.44 & 10.45 & 4.51 & 19.45 & $24 d$ & \\
\hline & 6.33 & 6.35 & 0.79 & 25.00 & لـ & \\
\hline & 2.46 & 8.18 & 13.57 & 20.85 & $16 \mathrm{~d}$ & \\
\hline & 11.39 & 11.22 & 7.16 & 24.82 & $24 \mathrm{~d}$ & \multirow[t]{2}{*}{ N225 } \\
\hline & 6.89 & 8.46 & 4.20 & 40.38 & $30 \mathrm{~d}-$ & \\
\hline & & & & $8^{7^{4}}$ & & \\
\hline
\end{tabular}

(b) $\quad$ N120 - N225

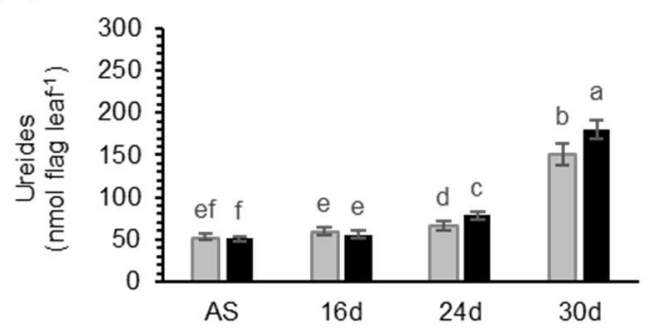

(c)

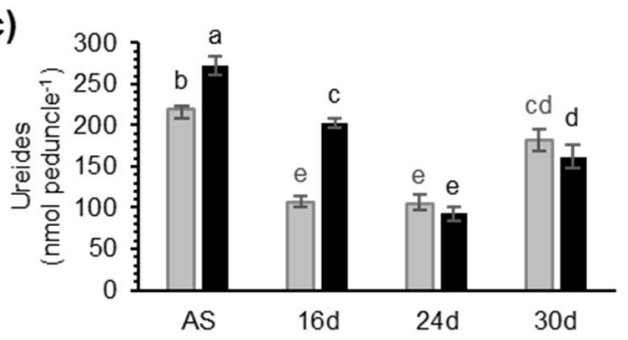

(d)

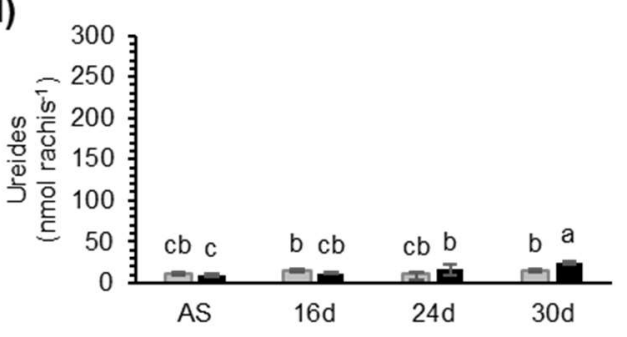

(e)

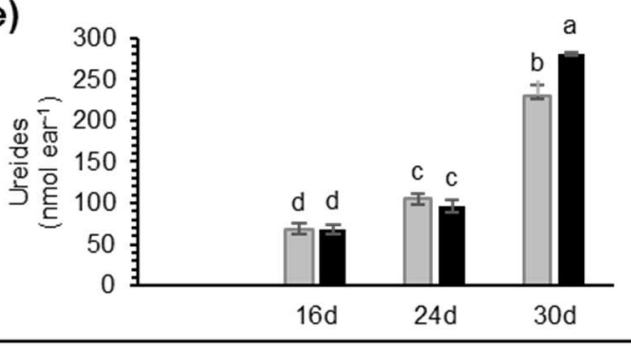

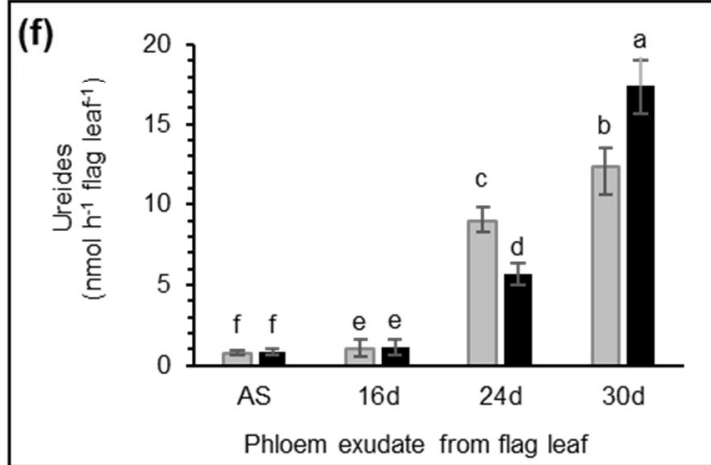

(g)

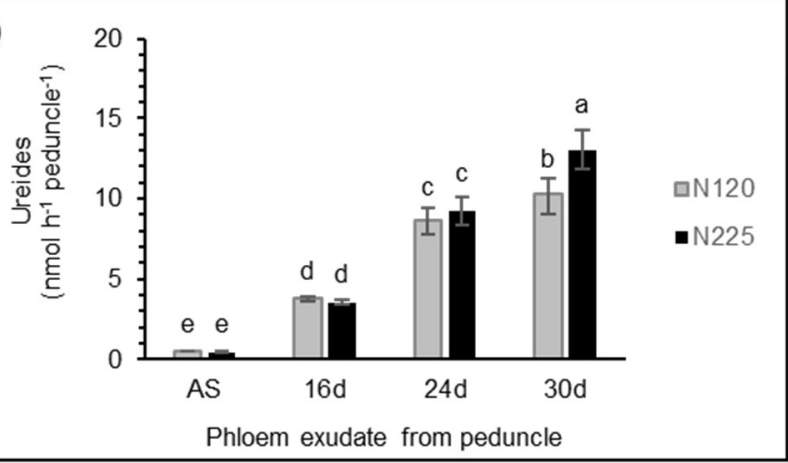

Figure 4. Characteristics of synthesis, transport, and degradation of ureides in wheat at the grain filling stage. (a) qRT-PCR analysis of the ureide metabolism genes in different organs in relation to $\mathrm{N}$ fertilization and development. The geometric mean of $C_{t}$ values of TaATPases and TaTEF served to normalize the expression ratio for each gene. Data in the figure are origin data and the means of six independent biological replicates. Gene expression data are shown as $\log _{2}$-transformed data of normalized data +1 . Ureides accumulation in the flag leaf $(\mathbf{b})$, peduncle (c), rachis (d), and ear (e) during grain filling grown under N120 and N225 conditions. The content of ureides in the phloem exudate of flag leaf (f) and peduncle (g) during grain filling grown under N120 and N225 conditions. Data are means of six independent biological replicates \pm SD. The different letters above each sample indicate statistically significant differences, where $p<0.05$ according to one-way ANOVA and Duncan post-hoc test. 


\section{Discussion}

In order to improve crop nitrogen use efficiency, GS has been studied numerous times owing to its essential role in $\mathrm{N}$ remobilization during grain filling $[8,10,15]$. The localization of GS1 in the vascular tissues and the developmental regulation of GS1 suggest that it is important for nitrogen remobilization [18,24]. Gene knock-out assay and QTL analyses in rice, maize, or wheat have shown that GS1 is necessary for grain filling $[8,14,15,31,34]$. In wheat, TaGS1 isozyme includes TaGS1;1, TaGS1;2, and TaGS1;3, but how they participate in $\mathrm{N}$ remobilization remains unclear.

\subsection{TaGS1;2-4A/4D Were Highly Expressed in Rachis and Peduncle during Grain Filling}

This study is the first to report that TaGS1;2-4A/4D had the highest expression level in the TaGS gene family, especially in rachis and peduncle during grain filling (Figure 1). Furthermore, GUS driven by the TaGS genes promoter had different transcriptional levels in Arabidopsis, among which ProTaGS1;2-4A/4D had the highest activity (Figure 2a). Only ProTaGS1;2-4A/4B/4D::GUS transgenic plants had GUS activity, and it was mainly distributed in the vascular tissues of the leaf, root, and petal (Figure $2 b$ ), which is consistent with the expression of TaGS1;2-4A/4D in wheat. Under natural light conditions, $T a G S 2-2 A / 2 D$ had a high expression level in the flag leaves of wheat (Figure 1), but no GUS activity was detected in ProTaGS2-2A/2B/2D::GUS transgenic plants. However, after $1 \mathrm{~h}$ of natural light induction, GUS activity could be detected in ProTaGS2-2A::GUS transgenic plant (Figure S2), indicating that the activity of $\operatorname{ProTaGS2}-2 \mathrm{~A}$ is regulated by light, which is consistent with our previous research [35].

\subsection{TaGS1;2 Participates in $\mathrm{N}$ Remobilization by Assimilating $\mathrm{NH}_{4}{ }^{+}$from Ureide Degradation}

GS activity is highly correlated with the amount of N remobilized [10], and GS1 overexpression can promote $\mathrm{N}$ remobilization from senescent leaves to developing ones in tobacco [36,37]. Glutamine synthetase is an enzyme, not a transporter or a carrier protein. How does GS participate in nitrogen remobilization? During leaf senescence, TaGS1;1 and TaGS1;2 fulfil a key function in $\mathrm{N}$ remobilization by assimilating $\mathrm{NH}_{4}{ }^{+}$ generated from protein degradation [18]. We found that TaGS1;2 and $\mathrm{NH}_{4}{ }^{+}$coexisted in the phloem of rachis and peduncle (Figure $3 a, b)$, and a large number of amino acids (mainly Gln) entered into grains through the phloem during grain filling [17]. These results suggest that $\mathrm{NH}_{4}{ }^{+}$in the phloem may be assimilated into Gln by TaGS1;2. In the phloem, the content of Gln is much higher than that of Glu [7]. TaGS1;2 has a high affinity for Glu and can be significantly activated by Gln [17], which is helpful for Gln synthesis in the phloem.

Where is the $\mathrm{NH}_{4}{ }^{+}$in phloem of peduncle and rachis from? The main sources of $\mathrm{NH}_{4}{ }^{+}$ in plants include direct absorption from soil by roots, $\mathrm{NO}_{3}{ }^{-}$reduction, photorespiration, and the degradation of protein and nucleic acid $[8,27]$. The $\mathrm{NH}_{4}{ }^{+}$absorbed by wheat from the soil is mainly directly assimilated into organic nitrogen by the roots and is rarely transported to the shoot in the form of $\mathrm{NH}_{4}{ }^{+}[19,38,39] . \mathrm{NH}_{4}{ }^{+}$from $\mathrm{NO}_{3}{ }^{-}$reduction and photorespiration is directly assimilated into Gln by GS2 [8,15,35], and this part of $\mathrm{NH}_{4}{ }^{+}$ is not transported among organs. It has been reported that protein degradation produces $\mathrm{NH}_{4}{ }^{+}$during leaf senescence [24,40], but we found that there was no obvious $\mathrm{NH}_{4}{ }^{+}$export from the phloem of flag leaves during grain filling (Figure 3b). During flag leaf senescence, degraded proteins were mainly exported in the form of amino acids, such as Gln and alanine (Ala) [17]. 
Nucleic acid is also an important N-containing organic molecule in plant tissues [27]. The content of the total nucleic acid in wheat flag leaves is about $2660 \mathrm{nmol} / \mathrm{g}$ DW [26]. During tissue senescence, the $\mathrm{N}$ of nucleic acid is mainly transported in the form of ureides [27]. Ureides are synthesized mainly in the flag leaf, then exported from the phloem of flag leaf into grain through phloem of peduncle and rachis, and eventually accumulate in the grain (Figure 4), which is consistent with Casartelli et al., who found allantoin accumulation in the grain [27]. TaAAH catalyzes the ureide degradation and releases $\mathrm{NH}_{4}{ }^{+}$[26]. The expression level of $\mathrm{TaAAH}$ was very low in flag leaves but high in grains, peduncle, and rachis (Figure 4a). The expression level of $T a A A H$ in grains was about 4-10 times that in flag leaves (Figure 4a), and the content of $\mathrm{NH}_{4}{ }^{+}$in grains is about five times that in flag leaves [17]. These results indicate that the high concentration of $\mathrm{NH}_{4}{ }^{+}$ in grains is related to degradation of ureides catalyzed by TaAAH.

The phloem of rachis is a major channel for ureides into grain. In rachis, the synthesis and accumulation of ureides was very low (Figure 4a,d), but the expression of TaAAH was high (Figure 4a), indicating that the ureides, during transportation, can be degraded by TaAAH. TaGS1;2, located in the phloem of rachis, can assimilate the $\mathrm{NH}_{4}{ }^{+}$released from ureide degradation. TaGS1;2 located in the phloem of peduncle, may also have a similar function. However, this hypothesis requires further research using in vivo ${ }^{15} \mathrm{~N}$ labelling experiments.

\subsection{TaGS1;2-4A Is a Candidate Gene for Improving Nitrogen Remobilization Efficiency in Wheat}

During grain filling, the expression of TaGS1;1 and TaGS1;2 are increased continuously $[18,24,41]$. However, the QTL for flag leaves GS activity is not colocalized with $T a G S 1 ; 1$ [32]. In this study, we found that the expression level of TaGS1;1-6A continued to decrease during grain filling, while the expression level of TaGS1;2-4A/4D continued to increase and was much higher than that of TaGS1;1-6A (Figure 1). In addition, the activity of ProTaGS1;2-4A/4D was much higher than ProTaGS1;1-6A in Arabidopsis (Figure 2a). These results suggest that $T a G S 1 ; 2-4 A / 4 D$ plays a more important role in the $\mathrm{N}$ remobilization in flag leaves.

In Arabidopsis, AtGln1;1-5 are expressed in the phloem of vascular tissue. AtGln1;1, $A t G \ln 1 ; 2$, and $A t G \ln 1 ; 3$ act together for $\mathrm{N}$ remobilization and seed filling [5]. In wheat, TaGS1;2 is widely distributed in the vascular tissues, especially in the phloem of peduncle, rachis (Figure 3a), and grain [17]. TaGS1;2 is mainly encoded by TaGS1;2-4A and TaGS1;2$4 D$, and TaGS1;2-4A has a higher expression level (Figure 1) and is closely related to QTL for GS activity in flag leaves and grain protein content [30,32], which suggests that TaGS1;2-4A may be a candidate gene for improving nitrogen remobilization efficiency.

In summary, our current study revealed a novel perspective on the role of glutamine synthetase in nitrogen remobilization in wheat. TaGS1;2 was highly expressed in the peduncle and rachis, and its promoter activity was widely distributed in vascular tissues, indicating that it is the main TaGS isozyme in $\mathrm{N}$ remobilization during grain filling in wheat. TaGS1;2 encoded by TaGS1;2-4A and TaGS1;2-4D was located in the phloem of the peduncle and rachis, which may participate in nitrogen remobilization by assimilating $\mathrm{NH}_{4}{ }^{+}$released from ureide degradation (Figure 5). 


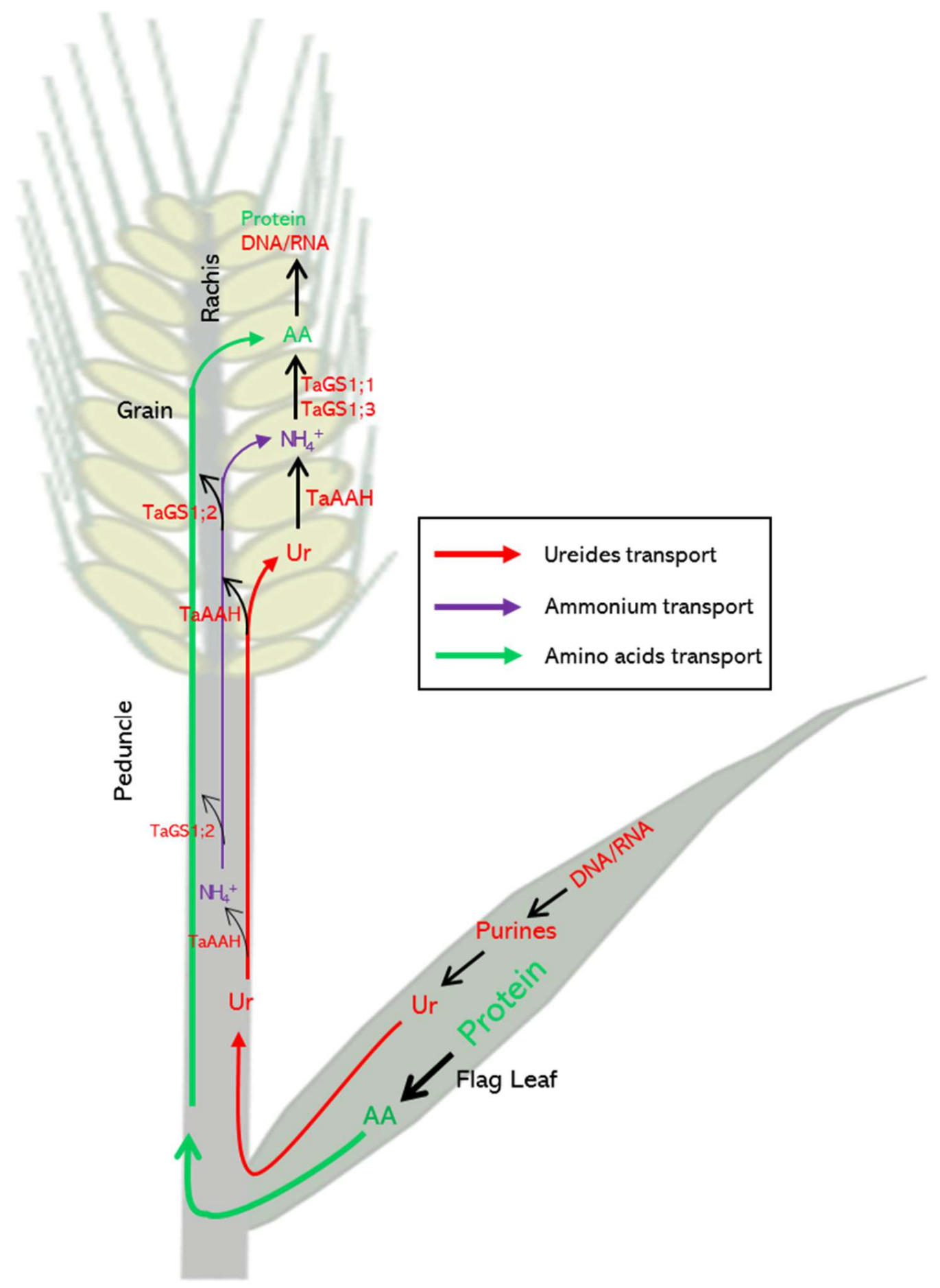

Figure 5. A schematic model of TaGS1;2 involved in the nitrogen remobilization pathway. The transport of ureides (Ur), $\mathrm{NH}_{4}{ }^{+}$, and amino acids (AA) is indicated by yellow, purple, and green arrows, respectively. Most of the ureides synthesized in flag leaves is transported to the grain via the phloem. During the transport, part of the ureides is degraded, and the released ammonium is assimilated into Gln by TaGS1;2, which is located in the phloem of the peduncle and rachis.

\section{Materials and Methods}

\subsection{Wheat Growth Conditions and Experimental Design}

The field experiment was conducted during the 2019-2020 growing season at the experimental station of Henan Agricultural University in Xuchang, Henan, China $\left(113^{\circ} 48^{\prime} 34^{\prime \prime} \mathrm{E}\right.$, $\left.34^{\circ} 7^{\prime} 56^{\prime \prime} \mathrm{N}\right)$. The Xuchang site is in the center of China and has a warm temperate con- 
tinental monsoon climate. Meteorological data, including air temperature and rainfall, were acquired for growth seasons from the meteorological station of Xuchang (Table S1). The previous crop was maize. The soil contained $16.2 \mathrm{~g}$ organic matter $\mathrm{kg}^{-1}, 1.30 \mathrm{~g}$ total $\mathrm{N} \mathrm{kg}^{-1}, 80.2 \mathrm{mg}$ water-hydrolyzable $\mathrm{N} \mathrm{kg}^{-1}, 15.4 \mathrm{mg}$ rapidly available phosphate $\mathrm{kg}^{-1}$, and $115.14 \mathrm{mg}$ rapidly available potassium $\mathrm{kg}^{-1}$. Two nitrogen fertilizer levels of 120 and $225 \mathrm{Kg} \mathrm{N}^{-1}$ were set up, represented by N120 and N225, respectively. The experiment was conducted in a field plot with a size of $8 \mathrm{~m} \times 2.4 \mathrm{~m}$ and repeated three times. Urea $(46.4 \% \mathrm{~N})$ was used as a nitrogenous fertilizer to perform the experiment. A total of $60 \%$ of the total $\mathrm{N}$ was directly mixed into the soil and combined with calcium superphosphate (120 kg ha $\left.{ }^{-1}\right)$ and potassium chloride $\left(120 \mathrm{~kg} \mathrm{ha}^{-1}\right)$ before plowing, and $40 \%$ was dissolved in water and applied to the soil at the elongation stage. The seeds of Yumai 49 (YM49) were sown on 17 October 2019 in rows at $20 \mathrm{~cm}$ spacing with 12 rows per plot at a density of 290 plants $\mathrm{m}^{-2}$. YM49 is one of the popularized cultivars in the Henan province of China and has the characteristics of a high and stable yield and high nitrogen use efficiency [41]. YM49 seeds were purchased from Henan Pingan Seed Co., Ltd. (Jiaozuo, China). Irrigation was carried out in the overwintering stage and stem elongation stage.

The anthesis stage was defined as more than $50 \%$ of the spikes within a plot showing protruding anthers. To track days after anthesis, the stems with normal development and uniform size were labeled at anthesis. At the anthesis stage (AS) and 16, 24, and 30 days after anthesis (DAA), the flag leaf, sheath, peduncle and rachis, and grain of 10 stems were mixed, frozen in liquid $\mathrm{N}$, and stored at $-80{ }^{\circ} \mathrm{C}$ for the measurement of physiological indicators and gene expression. Two samples were collected from each of the three plots for a total of six replicates. The middle parts of the flag leaf, peduncle, and rachis from plants at 16 DAA were sampled and immediately immersed in fixative for the immunolocalization studies.

\subsection{Quantitative Real-Time PCR}

Total RNA was extracted from plant tissue using HiPure HP Plant RNA Kit B (Guangzhou Magen Biotechnology Co. Ltd., Guangzhou, China) according to the manufacturer's protocols. cDNA was synthesized using the RT III Super Mix with dsDNase (Monad Biotech Co., Ltd., Shanghai, China). Quantitative real-time PCR (qRT-PCR) was performed on a Step One Real-Time PCR System (Life Technologies Corporation, Carlsbad, CA, USA) with SYBR Green qPCR Mix (Monad) for the assay. All primers (Sangon Biotech Co., Ltd., Shanghai, China) of the TaGS genes used for qRT-PCR analysis are shown in Table S2. The specificity of each pair was verified by melting curve analysis and sequencing of the products. According to Casartelli et al. [27], primers of TaXDH1, TaUOX, TaALN, and TaAAH were synthesized by Sangon. The primers are listed in Table S2. The qPCR mix was composed of $10 \mu \mathrm{L}$ SYBR Green qPCR Mix (Monad), $5 \mu \mathrm{L}$ diluted cDNA 1:20 $(v / v), 0.5 \mu \mathrm{L}$ forward primer and $10 \mu \mathrm{M}$ reverse primer, and $4 \mu \mathrm{L}$ of sterile nuclease-free water. The conditions for qRT-PCR were as follows: $95^{\circ} \mathrm{C}$ for $10 \mathrm{~min}, 40$ cycles of $95^{\circ} \mathrm{C}$ for $15 \mathrm{~s}, 58^{\circ} \mathrm{C}$ for $15 \mathrm{~s}$, and $72^{\circ} \mathrm{C}$ for $20 \mathrm{~s}$. Fluorescence readings were taken during the elongation step $\left(72{ }^{\circ} \mathrm{C}\right)$. Melting curves were obtained from 60 to $95{ }^{\circ} \mathrm{C}$ with a $0.5^{\circ} \mathrm{C}$ increase every $15 \mathrm{~s}$. The TaATPases (Ta54227) and TaTEF (Ta53964) were utilized as reference genes [42]. The geometric mean of $C_{t}$ values of TaATPases and TaTEF served to normalize the expression ratio for each gene. The relative expression levels of genes were calculated via the $2^{\wedge}(-\Delta \Delta \mathrm{Ct})$ method.

\subsection{Binary Constructs and Plant Transformations}

The wheat cultivar YM49 was used to isolate TaGS gene promoters. An amplification of approximately $2000 \mathrm{bp}$ of each TaGS gene promoter was performed using the genomic DNA of wheat leaves as templates. Gene-specific primer couples are listed in Table S3. The amplified PCR products were cloned into a pTOPO vector (Aidlab Biotechnologies Co., Ltd., Beijing, China) and fully sequenced. 
To construct the ProTaGS:GUS fusion gene, the promoters of each TaGS gene were amplified using these cloning vectors as templates. The primers are listed in Table S4. The PCR products were ligated into the binary vector pCAMBIA1301 between the EcoR I and Nco I sites. The recombinant vectors were constructed using ClonExpress One Step Cloning Kit (Vazyme Biotech Co., Ltd., Nanjing, China). The authenticity of the fusion constructs was confirmed by DNA sequencing, followed by transformation into Agrobacterium strain GV3101 for Arabidopsis stable transformation. Transgenic plants in the wild-type Columbia0 background were obtained by floral dipping [43] and selected for their hygromycin resistance. The resistant seedlings were transferred to soil and verified by genomic PCR. More than six transgenic plants were obtained for each construct. Only three selected representative lines were used in all our experiments.

\subsection{Expression Analysis of GUS in Transgenic Plants}

Total RNA was extracted from transgenic Arabidopsis using HiPure HP Plant RNA Kit B (Magen). cDNA was synthesized using the RTIII Super Mix with dsDNase (Monad). Quantitative real-time PCR (qRT-PCR) was performed on a Step One Real-Time PCR System (Life) with SYBR Green qPCR Mix (Monad) for the assay. The primers are listed in Table S2. AtUBQ11 were used as reference genes; relative expression levels of GUS were calculated via the $2^{\wedge}(-\Delta \Delta \mathrm{Ct})$ method.

\subsection{Histochemical GUS Staining Assay}

Plants carrying the ProTaGS::GUS construct were incubated in GUS staining solution $\left(50 \mathrm{mM} \mathrm{KH}_{2} \mathrm{PO}_{4}, 50 \mathrm{mM} \mathrm{K}_{2} \mathrm{HPO}_{4}, 10 \mathrm{mM} \mathrm{Na}{ }_{2}\right.$ EDTA, 0.1\% (v/v) Triton X-100, $0.5 \mathrm{mM}$ ferricyanide, $0.5 \mathrm{mM}$ ferrocyanide, and $20 \mathrm{mM}$ 5-bromo-4-chloro-3-indolyl- $\beta$-D-glucuronic acid (X-Glc A)) at $37^{\circ} \mathrm{C}$ for $12 \mathrm{~h}$ and then decolorized by $75 \%$ ethanol solution for three days. A stereomicroscope (OLYMPUS SZX16) with a maximum magnification of 20 times was used to analyze and photograph the GUS staining.

\subsection{Cellular Localization of TaGS1;2 Using Immunofluorescence Analysis}

The tissues of flag leaf, peduncle, and rachis were fixed in FAA fixative for at least $24 \mathrm{~h}$. Their embedding in paraffin, sectioning, and immunofluorescence was performed by Servicebio (Wuhan Servicebio Technology Co., Ltd., Wuhan, Hubei, China). Anti-TaGS1;2 antibodies were diluted 1:200 in blocking solution. The specific antibodies of TaGS1;2 isoform was prepared in our previous study, which could monospecifically recognize TaGS1;2 subunits [17].

Negative controls were conducted by substituting the TaGS monospecific antibodies with preimmune rabbit serum (Figure S1). Microscopy detection and images were collected with fluorescent microscopy (Nikon Co., Ltd., Tokyo, Japan). DAPI glowed blue by a UV excitation wavelength of 330-380 nm and an emission wavelength of $420 \mathrm{~nm}$; FITC glowed green by an excitation wavelength of 465-495 $\mathrm{nm}$ and an emission wavelength of 515-555 nm.

\subsection{Extraction of Proteins from Wheat Rachis and Western Blot Analysis}

Approximately $0.3 \mathrm{~g}$ fine homogeneous powder was mixed with $0.9 \mathrm{~mL}$ of GS extraction buffer (100 mM Tris, $1 \mathrm{mM}$ EDTA, $1 \mathrm{mM} \mathrm{MgCl}$, $1 \mathrm{mM}$ phenylmethanesulfonyl fluoride (PMSF), and $10 \mathrm{mM} \beta$-mercaptoethanol; $\mathrm{pH} 7.6)$ by shaking at $4^{\circ} \mathrm{C}$ for $10 \mathrm{~min}$. The extract was centrifuged at $12,000 \times g$ at $4{ }^{\circ} \mathrm{C}$ for $30 \mathrm{~min}$. The supernatant was then prepared for further experiments. Soluble protein content was determined by the Coomassie blue dye binding method using bovine serum albumin as a standard. 
Western blotting was performed in accordance with a previously described method [17]. A total of $5 \mu \mathrm{g}$ of soluble protein extracted from the rachis was loaded onto each lane. Proteins were separated in $12.5 \%(w / v)$ polyacrylamide gel and electrophoretically transferred to $0.45 \mu \mathrm{m}$ pore size PVDF membranes (Merck Millipore Ltd., Darmstadt, Germany) in transfer buffer ( $25 \mathrm{mM}$ Tris-base and $192 \mathrm{mM} \mathrm{Gly,} \mathrm{10 \%} \mathrm{methanol)} \mathrm{at} 200 \mathrm{~mA}$ for $50 \mathrm{~min}$. The membranes were blocked with TBST (20 mM Tris-base, $150 \mathrm{mM} \mathrm{NaCl}$, and $0.05 \%(v / v)$ Tween 20; pH 7.4) containing 5\% skimmed milk at $4{ }^{\circ} \mathrm{C}$ overnight. The PVDF membrane was incubated at $20^{\circ} \mathrm{C}$ for $1.5 \mathrm{~h}$ with the TaGS1;2 antibody, and the dilution ratio of the antibody was 1:30,000. After washing three times with TBST, the membrane was incubated at room temperature for $1 \mathrm{~h}$ with horseradish peroxidase-conjugated goat anti-rabbit IgG (ABclonal Biotechnology Co., Ltd., Hubei, China) at 1:25,000. After several washes with TBST, the membrane was incubated at room temperature for $5 \mathrm{~min}$ using Omni-ECL ${ }^{\mathrm{TM}}$ Femto Light Chemiluminescene Kit (EpiZyme Biotech Co., Ltd., Shanghai, China); the signals were detected by ChemiDocTM XRS ${ }^{+}$Imaging System (Bio-Rad Laboratories, Lnc., Hercules, CA, USA).

\subsection{Phloem Exudate Collection}

At AS and 16, 24, and 30 DAA, the phloem exudates of flag leaves were collected according to Simpson and Dalling [44], with some modifications. Flag leaves (containing about $5 \mathrm{~cm}$ sheath) were removed from the plants and recut under water before rapid immersion in the collection solution (10 mM HEPES and $10 \mathrm{mM}$ EDTA, adjusted to $\mathrm{pH}$ 7.5 with $\mathrm{NaOH}$ ). After $15 \mathrm{~min}$, the leaves were transferred to a fresh collection solution for phloem exudate collection. Three flag leaves were placed in a $1 \mathrm{~mL}$ collection solution in a dark and humid chamber. Exudates were collected over $4 \mathrm{~h}$ from 11:00 to 15:00 $\mathrm{h}$ Beijing time.

Phloem exudate collection of peduncles was carried out according to Wei et al. [17] with some modifications. At AS and 16, 24, and 30 DAA, the phloem exudates of peduncles on the stems were collected. The spike was cut off, and the peduncle under water was recut before rapid immersion in the collection buffer. After $15 \mathrm{~min}$, the exudates from peduncle to spike were collected with a fresh collection solution. For each experiment, peduncle was placed in $1 \mathrm{~mL}$ collection solution in a dark and humid chamber. Exudates were collected over 4, from 12:00 to 16:00 $\mathrm{h}$ Beijing time.

Ammonium content was measured according to Wei et al. [36]; total ureides level was analyzed according to Collier and Tegeder [45].

\subsection{Statistics}

All data represent the mean \pm standard deviation (SD) of six biological replicates. The datasets were analyzed using Microsoft Excel (2016, Microsoft, Redmond, WA, USA). Data were statistically analyzed using SPSS version 13.0 (IBM, Chicago, IL, USA). One-way analysis of variance (ANOVA) with a Duncan post-hoc test was used to test statistical differences.

Supplementary Materials: The following are available online at https:/ / www.mdpi.com/article/10 .3390/ijms222011083/s1.

Author Contributions: Conceptualization, Y.W. and X.W. (Xiaochun Wang); data curation, H.L.; formal analysis, B.Q.; funding acquisition, X.M. and X.W. (Xiaochun Wang); investigation, Y.W. and L.W.; methodology, L.W.; project administration, X.M.; software, X.Z.; supervision, Z.Z.; validation, H.L. and X.W. (Xiaoran Wang); visualization, L.W.; writing-original draft, Y.W.; writing-review and editing, X.W. (Xiaochun Wang). All authors have read and agreed to the published version of the manuscript.

Funding: This research was funded by the National Natural Science Foundation of China, grant number 32071956, and the Modern Agricultural Technology System in Henna province, grant number S2010-01-G04. 
Acknowledgments: The authors would like to thank Tao Li for giving us the pCAMBIA1301 vector.

Conflicts of Interest: The authors declare no conflict of interest.

$\begin{array}{ll}\text { Abbreviations } \\ \text { GS } & \text { glutamine synthetase } \\ \mathrm{N} & \text { nitrogen } \\ \mathrm{NH}_{4}^{+} & \text {ammonium } \\ \mathrm{NO}_{3}^{-} & \text {nitrate } \\ \mathrm{NUE} & \text { nitrogen use efficiency } \\ \text { ALN } & \text { allantoinas allantoinase } \\ \text { AAH } & \text { allantoate amidohydrolase } \\ \text { XDH } & \text { xanthine dehydrogenase } \\ \text { UOX } & \text { urate oxidase } \\ \text { QTL } & \text { quantitative trait locus }\end{array}$

\section{References}

1. De Oliveira Silva, A.; Ciampitti, I.A.; Slafer, G.A.; Lollato, R.P. Nitrogen utilization efficiency in wheat: A global perspective. Eur. J. Agron. 2020, 114, 126008. [CrossRef]

2. Hirel, B.; Le Gouis, J.; Ney, B.; Gallais, A. The challenge of improving nitrogen use efficiency in crop plants: Towards a more central role for genetic variability and quantitative genetics within integrated approaches. J. Exp. Bot. 2007, 58, $2369-2387$. [CrossRef]

3. Xu, G.; Fan, X.; Miller, A.J. Plant Nitrogen Assimilation and Use Efficiency. Annu. Rev. Plant Biol. 2012, 63, 153-182. [CrossRef] [PubMed]

4. Tilman, D.; Cassman, K.G.; Matson, P.A.; Naylor, R.; Polasky, S. Agricultural sustainability and intensive production practices. Nature 2002, 418, 671-677. [CrossRef]

5. Moison, M.; Marmagne, A.; Dinant, S.; Soulay, F.; Azzopardi, M.; Lothier, J.; Citerne, S.; Morin, H.; Legay, N.; Chardon, F.; et al Three cytosolic glutamine synthetase isoforms localized in different-order veins act together for $\mathrm{N}$ remobilization and seed filling in Arabidopsis. J. Exp. Bot. 2018, 69, 4379-4393. [CrossRef]

6. Kant, S.; Bi, Y.-M.; Rothstein, S.J. Understanding plant response to nitrogen limitation for the improvement of crop nitrogen use efficiency. J. Exp. Bot. 2010, 62, 1499-1509. [CrossRef]

7. Peeters, K.M.U.; Van Laere, A.J. Amino acid metabolism associated with N-mobilization from the flag leaf of wheat (Triticum aestivum L.) during grain development. Plant Cell Environ. 1994, 17, 131-141. [CrossRef]

8. Bernard, S.M.; Habash, D.Z. The importance of cytosolic glutamine synthetase in nitrogen assimilation and recycling. New Phytol. 2009, 182, 608-620. [CrossRef] [PubMed]

9. Guan, M.; Møller, I.; Schjoerring, J. Two cytosolic glutamine synthetase isoforms play specific roles for seed germination and seed yield structure in Arabidopsis. J. Exp. Bot. 2015, 66, 203-212. [CrossRef]

10. Kichey, T.; Hirel, B.; Heumez, E.; Dubois, F.; Le Gouis, J. In winter wheat (Triticum aestivum L.), post-anthesis nitrogen uptake and remobilisation to the grain correlates with agronomic traits and nitrogen physiological markers. Field Crops Res. 2007, 102, 22-32. [CrossRef]

11. Gao, Y.; de Bang, T.C.; Schjoerring, J.K. Cisgenic overexpression of cytosolic glutamine synthetase improves nitrogen utilization efficiency in barley and prevents grain protein decline under elevated $\mathrm{CO}_{2}$. Plant Biotechnol. J. 2019, 17, 1209-1221. [CrossRef]

12. Kichey, T.; Heumez, E.; Pocholle, D.; Pageau, K.; Vanacker, H.; Dubois, F.; Le, G.J.; Hirel, B. Combined agronomic and physiological aspects of nitrogen management in wheat highlight a central role for glutamine synthetase. New Phytol. 2006, 169, 265-278. [CrossRef] [PubMed]

13. Ishiyama, K.; Inoue, E.; Tabuchi, M.; Yamaya, T.; Takahashi, H. Biochemical background and compartmentalized functions of cytosolic glutamine synthetase for active ammonium assimilation in rice roots. Plant Cell Physiol. 2004, 45, 1640-1647. [CrossRef] [PubMed]

14. Martin, A.; Lee, J.; Kichey, T.; Gerentes, D.; Zivy, M.; Tatout, C.; Dubois, F.; Balliau, T.; Valot, B.; Davanture, M.; et al. Two Cytosolic Glutamine Synthetase Isoforms of Maize Are Specifically Involved in the Control of Grain Production. Plant Cell 2006, 18, 3252-3274. [CrossRef]

15. Thomsen, H.C.; Eriksson, D.; Møller, I.S.; Schjoerring, J.K. Cytosolic glutamine synthetase: A target for improvement of crop nitrogen use efficiency? Trends Plant Sci. 2014, 19, 656-663. [CrossRef] [PubMed]

16. Wang, X.; Wang, L.; Zhang, Z.; Qin, B.; Yu, M.; Wei, Y.; Ma, X. Transcription characteristics of wheat glutamine synthetase isoforms and the sequence analysis of their promoters. Acta Agron. Sin. 2021, 47, 761-769. 
17. Wei, Y.; Xiong, S.; Zhang, Z.; Meng, X.; Wang, L.; Zhang, X.; Yu, M.; Yu, H.; Wang, X.; Ma, X. Localization, Gene Expression, and Functions of Glutamine Synthetase Isozymes in Wheat Grain (Triticum aestivum L.). Front. Plant Sci. 2021, 12, 580405. [CrossRef]

18. Bernard, S.M.; Møller, A.L.B.; Dionisio, G.; Kichey, T.; Jahn, T.P.; Dubois, F.; Baudo, M.; Lopes, M.S.; Tercé-Laforgue, T.; Foyer, C.H.; et al. Gene expression, cellular localisation and function of glutamine synthetase isozymes in wheat (Triticum aestivum L.). Plant Mol. Biol. 2008, 67, 89-105. [CrossRef]

19. Wei, Y.; Wang, X.; Zhang, Z.; Xiong, S.; Meng, X.; Zhang, J.; Wang, L.; Zhang, X.; Yu, M.; Ma, X. Nitrogen Regulating the Expression and Localization of Four Glutamine Synthetase Isoforms in Wheat (Triticum aestivum L.). Int. J. Mol. Sci. 2020, 21, 6299. [CrossRef] [PubMed]

20. Hu, M.; Zhao, X.; Liu, Q.; Hong, X.; Zhang, W.; Zhang, Y.; Sun, L.; Li, H.; Tong, Y. Transgenic expression of plastidic glutamine synthetase increases nitrogen uptake and yield in wheat. Plant Biotechnol. J. 2018, 16, 1858-1867. [CrossRef]

21. Kozaki, A.; Takeba, G. Photorespiration protects C3 plants from photooxidation. Nature 1996, 384, 557-560. [CrossRef]

22. Rentsch, D.; Schmidt, S.; Tegeder, M. Transporters for uptake and allocation of organic nitrogen compounds in plants. FEBS Lett. 2007, 581, 2281-2289. [CrossRef]

23. Zhang, L.; Tan, Q.; Lee, R.; Trethewy, A.; Lee, Y.H.; Tegeder, M. Altered xylem-phloem transfer of amino acids affects metabolism and leads to increased seed yield and oil content in Arabidopsis. Plant Cell 2010, 22, 3603-3620. [CrossRef]

24. Kichey, T.; Le Gouis, J.; Sangwan, B.; Hirel, B.; Dubois, F. Changes in the Cellular and Subcellular Localization of Glutamine Synthetase and Glutamate Dehydrogenase During Flag Leaf Senescence in Wheat (Triticum aestivum L.). Plant Cell Physiol. 2005, 46, 964-974. [CrossRef]

25. Guiboileau, A.; Yoshimoto, K.; Soulay, F.; Bataillé, M.P.; Avice, J.C.; Masclaux-Daubresse, C. Autophagy machinery controls nitrogen remobilization at the whole-plant level under both limiting and ample nitrate conditions in Arabidopsis. New Phytol. 2012, 194, 732-740. [CrossRef] [PubMed]

26. Melino, V.J.; Casartelli, A.; George, J.; Rupasinghe, T.; Roessner, U.; Okamoto, M.; Heuer, S. RNA Catabolites Contribute to the Nitrogen Pool and Support Growth Recovery of Wheat. Front. Plant Sci. 2018, 9, 1539. [CrossRef] [PubMed]

27. Casartelli, A.; Melino, V.J.; Baumann, U.; Riboni, M.; Suchecki, R.; Jayasinghe, N.S.; Mendis, H.; Watanabe, M.; Erban, A.; Zuther, E.; et al. Opposite fates of the purine metabolite allantoin under water and nitrogen limitations in bread wheat. Plant Mol. Biol. 2019, 99, 477-497. [CrossRef] [PubMed]

28. Tegeder, M.; Masclaux-Daubresse, C. Source and sink mechanisms of nitrogen transport and use. New Phytol. 2018, 217, 35-53. [CrossRef] [PubMed]

29. Hörtensteiner, S.; Feller, U. Nitrogen metabolism and remobilization during senescence. J. Exp. Bot. 2002, 53, 927-937. [CrossRef]

30. Gadaleta, A.; Nigro, D.; Giancaspro, A.; Blanco, A. The glutamine synthetase (GS2) genes in relation to grain protein content of durum wheat. Funct. Integr. Genomic. 2011, 11, 665-670. [CrossRef] [PubMed]

31. Gadaleta, A.; Nigro, D.; Marcotuli, I.; Giancaspro, A.; Giove, S.L.; Blanco, A. Isolation and characterisation of cytosolic glutamine synthetase (GSe) genes and association with grain protein content in durum wheat. Crop Pasture Sci. 2014, 65, 38-45. [CrossRef]

32. Habash, D.Z.; Bernard, S.; Schondelmaier, J.; Weyen, J.; Quarrie, S.A. The genetics of nitrogen use in hexaploid wheat: N utilisation, development and yield. Theor. Appl. Genet. 2007, 114, 403-419. [CrossRef]

33. Takagi, H.; Watanabe, S.; Tanaka, S.; Matsuura, T.; Mori, I.C.; Hirayama, T.; Shimada, H.; Sakamoto, A. Disruption of ureide degradation affects plant growth and development during and after transition from vegetative to reproductive stages. BMC Plant Biol. 2018, 18, 287. [CrossRef]

34. Tabuchi, M.; Sugiyama, K.; Ishiyama, K.; Inoue, E.; Sato, T.; Takahashi, H.; Yamaya, T. Severe reduction in growth rate and grain filling of rice mutants lacking OsGS1;1, a cytosolic glutamine synthetase1;1. Plant J. 2005, 42, 641-651. [CrossRef] [PubMed]

35. Wang, X.; Wei, Y.; Shi, L.; Ma, X.; Theg, S.M. New isoforms and assembly of glutamine synthetase in the leaf of wheat (Triticum aestivum L.). J. Exp. Bot. 2015, 66, 6827-6834. [CrossRef] [PubMed]

36. Wei, Y.; Shi, A.; Jia, X.; Zhang, Z.; Ma, X.; Gu, M.; Meng, X.; Wang, X. Nitrogen Supply and Leaf Age Affect the Expression of TaGS1 or TaGS2 Driven by a Constitutive Promoter in Transgenic Tobacco. Genes 2018, 9, 406. [CrossRef]

37. Fuentes, S.I.; Allen, D.J.; Ortiz-Lopez, A.; Hernández, G. Over-expression of cytosolic glutamine synthetase increases photosynthesis and growth at low nitrogen concentrations. J. Exp. Bot. 2001, 52, 1071-1081. [CrossRef]

38. Ikeda, M.; Kusano, T.; Koga, N. Carbon skeletons for amide synthesis during ammonium nutrition in tomato and wheat roots. Soil Sci. Plant Nutr. 2004, 50, 141-147. [CrossRef]

39. Funayama, K.; Kojima, S.; Tabuchi-Kobayashi, M.; Sawa, Y.; Nakayama, Y.; Hayakawa, T.; Yamaya, T. Cytosolic Glutamine Synthetase1;2 is Responsible for the Primary Assimilation of Ammonium in Rice Roots. Plant Cell Physiol. 2013, 54, 934-943. [CrossRef]

40. Brugière, N.; Dubois, F.; Masclaux, C.; Sangwan, R.S.; Hirel, B. Immunolocalization of glutamine synthetase in senescing tobacco (Nicotiana tabacum L.) leaves suggests that ammonia assimilation is progressively shifted to the mesophyll cytosol. Planta 2000, 211, 519-527. [CrossRef]

41. Zhang, Z.; Xiong, S.; Wei, Y.; Meng, X.; Wang, X.; Ma, X. The role of glutamine synthetase isozymes in enhancing nitrogen use efficiency of N-efficient winter wheat. Sci. Rep. 2017, 7, 1000. [CrossRef] [PubMed]

42. Paolacci, A.R.; Tanzarella, O.A.; Porceddu, E.; Ciaffi, M. Identification and validation of reference genes for quantitative RT-PCR normalization in wheat. BMC Mol. Biol. 2009, 10, 11. [CrossRef] 
43. Clough, S.J.; Bent, A.F. Floral dip: A simplified method for Agrobacterium-mediated transformation of Arabidopsis thaliana. Plant J. 1998, 16, 735-743. [CrossRef] [PubMed]

44. Simpson, R.J.; Dalling, M.J. Nitrogen redistribution during grain growth in wheat (Triticum aestivum L.). Planta 1981, 151, 447-456. [CrossRef] [PubMed]

45. Collier, R.; Tegeder, M. Soybean ureide transporters play a critical role in nodule development, function and nitrogen export. Plant J. 2012, 72, 355-367. [CrossRef] 